\title{
MUSEOLOGI OCH MUSEER
}

I den i Sverige nyligen offentliggjorda statliga utredningen "Minne och bildning. Museernas uppdrag och organisation" (SOU 1994:51) beklagar utredarna det bristfälliga underlag som finns för studiet och bedömningen av museers verksamhet. Alltför få källor kan ge information och kunskap om de system, vari museiväsendet fungerar, om de kraftfält som påverkar och ger innehåll åt verksamheten, om samhällsmedborgarnas förväntningar på och utbyte av museerna.

Många uppgifter yppar sig här för museologiskt studium. Det ligger nära till hands att koppla de nu officiellt bekräftade behoven samman med de allt enträgnare kraven från fackligt håll på att museologin/museivetenskapen måste byggas ut vid universiteten - dels som ett obligatorisk inslag i grundutbildningen för museiverksamhet och kulturmiljövård, dels - och kanske framförallt - som ett forskningsämne.

Museihistorien tecknas traditionellt som en enkel utvecklingslinje från primitivt samlande till nutidens mångformiga museilandskap. När termen genealogi valdes för rubriken på förra årets museidagar i Köpenhamn, var avsikten att kontrastera historisk komplexitet, variation och slumpmässighet mot den gängse lineära framställningen av museiinstitutionens historia. Inslag av detta betraktelsesätt mötte i många av bidragen när museernas arvsmassa skärskådades. En sammansatt bild framträdde, i och för sig besläktad med de flesta kulturinstitutioners historiska framträdelseformer. Museer förändrar sig språngvis och ofta på oväntade ställen; arvsmassan är ojämnt fördelad och manifesterar sig i oförutsebara mutationer som - när ett museum reagerar på utmaningar från det omgivande samhället - föder nya verksamhetsformer. Gravitationskrafter i offentlighetens ständiga idéproduktion kan plötsligt uppträda, som gör historieförvaltande institutioner till viktiga arenor för samhällsdebatt.

I den statliga utredningen är 'det öppna museet' och 'det lärande museet' honnörsbegrepp. En intressant museologisk uppgift vore att ta upp ett närstudium av de samverkande faktorer som vid olika tillfällen öppnat museer och gjort dem till 
NORDISK MUSEOLOGI $1994 \cdot 2$

genuina samhälleliga företag. Erfarenheter kunde hämtas fram av värde för framtiden och lärdomar dras som inte enbart är grundade på tidsbundna avsiktsdeklarationer och förmodanden inhämtade genom enkäter och intervjuer i en utredningssituation. Häri kunde museologin visa sin - inte sällan ifrågasatta - nyttighet för museerna.

I de uppsatser som ingår i föreliggande tidskriftsnummer finns i sammanhanget särskild anledning att framhålla Walter Grasskamps och Erik Hofréns texter, där viktiga uppslag för museologisk forskning finns.

Erik Hofréns reflexioner om museerna som makt och möjlig motmakt i offentligheten är för övrigt skrivna särskilt för tidskriften. Björnar Olsens och Asgeir Svestads uppmärksammade analys av museisamlingars roll för konstruktionen av begreppet förhistoria, Mogens Bencards diskussion av sambandet mellan konstkammare och offentligt museum, Marie-Louise von Plessens synpunkter på övergången från furstesamling till nationalmuseum, Beat Wyss' analys av det fascinerande Tübingen-dokumentet från 1796/97 skrivet av Schelling, Hölderlin och Hegel samt Walter Grasskamps jämförelse mellan encyklopedi och museum - alla dessa texter presenterades under museidagarna i Köpenhamn och avrundar den i föregående nummer inledda redovisningen därifrån.

Numret har kunnat utges tack vare anslag från Norsk Museumsutvikling, Museumshöjskolen i Danmark och Finlands Museiförbund. Ännu är prenumerantskaran begränsad, men vi hoppas från redaktionens sida på en snabb tillväxt innevarande år. Kära läsare - hjälp oss därför att göra reklam för tidskriften! Och hör av er med synpunkter på innehållet och förslag till ämnen för kommande nummer! Per-Uno Ägren

\footnotetext{
Apropå -

att levandegörandet (eller Lazarus-köret som det ibland mera vanvördigt kallas) har kommit på modet i museernas och kulturmiljövårdens ansträngningar att demonstrera sin samhällsnytta - meddelas följande tyska läsövning: Geschichte ist so starr wie eine Leiche, sie ist das Tote und darum Unveränderliche, auch Unwiderrufliche. Geschichte ist leichenstarr, darum kann man Geschichte nicht "erleben". Fängt man an, Geschichte fïr das Erlebnis zuzubereiten, so löscht man ihre Geschichtlichkeit, hebt ihre unwiderrufliche Faktizität auf. Stumm spottet dieser Lazarus der Beschwörung, er verharrt in seinem Grabe. Ur: Dolf Sternbergers "Unzusammenhängende Notizen über Geschichte" (Mercur 41, 1987).
} 